\title{
Immune Response Modulation by Tumor-Secreted Glycosphingolipids
}

Ricardo D Lardone, Ingrid Cely, Peter A Sieling, and Delphine J Lee*

Dirks/Dougherty Laboratory for Cancer Research, Department of Translational Immunology, John Wayne Cancer Institute at Providence Saint John's Health Center, Santa Monica, CA 90404, USA

"Corresponding author: Delphine J Lee, Dirks/Dougherty Laboratory for Cancer Research, Department of Translational Immunology, John Wayne Cancer Institute at Providence Saint John's Health Center, Santa Monica, CA 90404, USA, Tel: 310-449-5265; Fax: 310-449-5273; E-mail: leedj@jwci.org

Rec date: Mar 25, 2014, Acc date: Apr 23, 2014, Pub date: Apr 25, 2014

Copyright: (c) 2014 Delphine $\mathrm{J}$ lee, et al. This is an open-access article distributed under the terms of the Creative Commons Attribution License, which permits unrestricted use, distribution, and reproduction in any medium, provided the original author and source are credited.

\begin{abstract}
Although originally considered merely structural components of cellular membranes, glycosphingolipids (GSL) are now recognized as having critical effects on cellular physiology, including proliferation, differentiation, viral transformation and ontogenesis. In addition, a vast majority of human cancers have modified GSL composition compared to parental normal cells. These modifications may contribute to both tumor survival and exert striking effects on anti-tumor immunity. In this review, we discuss mechanisms of immune modulation by tumor-secreted GSL.
\end{abstract}

Keywords: Glycosphingolipids; Anti-tumor immunity; Cancer

\section{Introduction}

Since their first isolation from human brain by JLW Thudichum in the late 1800 's, glycosphingolipids (GSL; lipid-rich molecules, widely expressed in normal tissues) were considered mere structural components of cell membranes. Over time, numerous reports have described changes in GSL composition and levels associated with cell proliferation, differentiation, viral transformation and ontogenesis [1].

A vast majority of human cancers exhibit striking differences in GSL composition when compared to parental normal cells (reviewed in [2]). These modifications may contribute to both tumor survival and exert striking effects on anti-tumor immunity. In this review, we describe mechanisms of GSL-mediated immune-modulation.

\section{Glycosphingolipids: structure and function in homeostasis}

Glycosphingolipids (GSL) are a group of complex lipids that exhibit amphipathic features, allowing their insertion into cellular bilayers. Their amphipathic nature derives from the presence of a lipid region (consisting on $\mathrm{N}$-acylsphingosine, or ceramide) covalently linked to a glycosidic region [3], as exemplified in Figure 1a. Ceramide may contain variations in either the sphingosine or the fatty acid (such as chain length, hydroxylation and/or saturation degree). Regarding the glycosidic region, it can vary in number and sequence of glycans, which in addition can have variability in their glucidic position and anomeric configuration. This structural versatility might explain the existence of more than 200 different GSL known up to date, which have been purified from a wide diversity of eukaryotic organisms [4]. This variability is relevant because, just as the primary sequence of proteins influences their secondary and tertiary structures, the specific oligosaccharides present in GSL, glycoproteins and other glycoconjugates affect the molecules' three-dimensional conformation $[5]$.

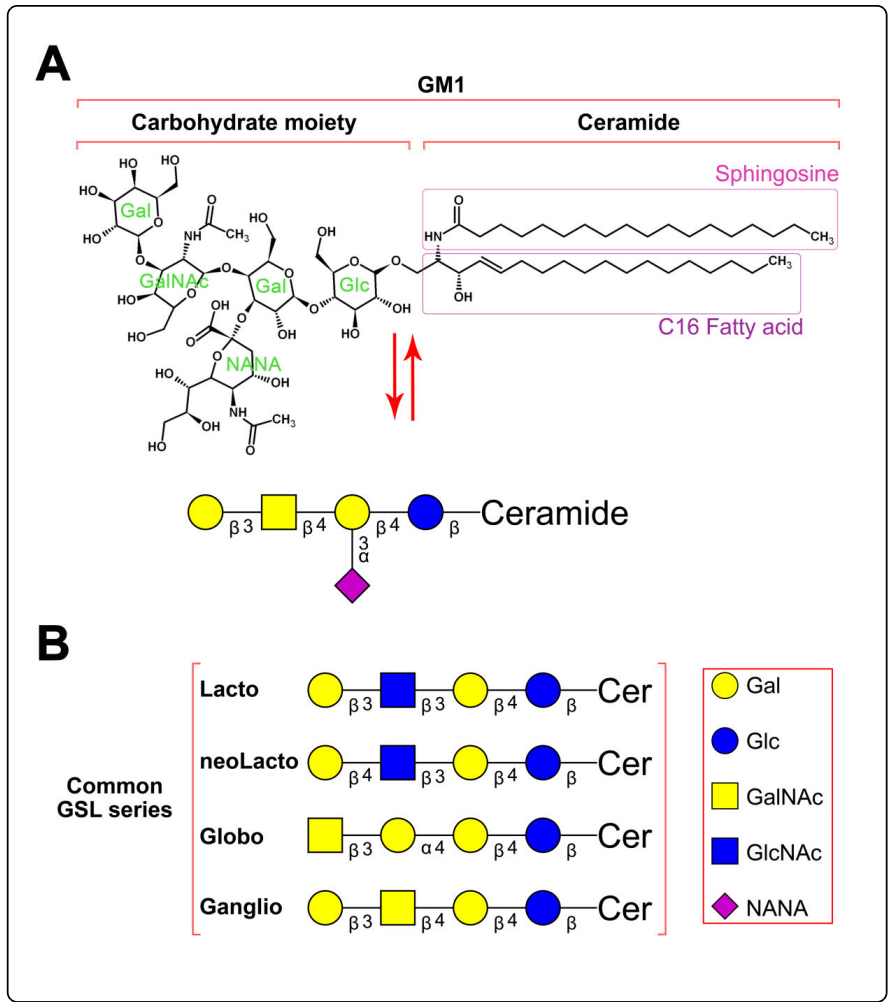

Figure 1: Structural features and variability of GSL. A, $\mathrm{GM}_{1}$ as an example of a GSL structure. The different components accounting for the amphipathic behavior of GSL (carbohydrate and ceramide moieties) are exhibited, along with its equivalent schematic representation in accordance to the "Consortium for Functional Glycomics" recommendations. B, Names and structure sequences for the main mammal GSL series having altered expression in tumors. 
GSL are classified based on the closest neutral glycosidic sequences bound to the ceramide domain. Each group of GSL being metabolic intermediates along the different biosynthetic pathways that sequentially add carbohydrates to ceramide is known as a "series". These neutral core structures can further elongate by adding a variable number of molecules, including $\mathrm{N}$-acetyl neuraminic acid (sialic acid) residues. The major GSL correlating with specific tumors belong mostly to four series: lacto-, neolacto-, globo- and ganglio-series. Figure $1 \mathrm{~b}$ exhibits the core sequences for these four main series.

GSL make up a significant portion of most eukaryotic cell membranes, adopting unique patterns for each cell type. Molar ratios of these molecules related to other major membrane lipids (such as phospholipids, cholesterol and glycerolipids) range from very low (i.e., $<5 \%$ in erythrocytes) to relatively high (i.e., $>30 \%$ of total lipids on oligodendrocytes plasma membrane, [6]). Surface-labeling experiments indicate GSL are inserted in the external layer of the cell through ceramide, and by their presence in the membrane regulate cell signaling. This is accomplished by altering the distribution of receptors in the cell membrane and by directly interacting or forming lipid domains that have preferential affinity for certain proteins, thus modifying their function [7]. GSL may also modulate cellular physiology by specifically binding other GSL or adjacent cell proteins to influence cell-cell or cell-environment interactions that regulate differentiation, cell growth and tissue organization [8-15].

\section{Regulatory mechanisms of glycosphingolipid synthesis and their disruption in tumor cells}

General mechanisms of GSL synthesis. GSL are not direct products of genes. Instead, they are synthesized through a complex series of coordinated biosynthetic pathways comprised of several integral membrane glycosyltransferases. Eukaryotic GSL synthesis begins in the endoplasmic reticulum (ER) with the formation of the lipophilic ceramide tail. The $\beta$-addition of either a galactose (on the luminal face of the ER) or a glucose residue (on the cytoplasmic face of the ER and early Golgi complex) to the 1-hydroxyl of ceramide generates GalCer or GlcCer, respectively. Once at the Golgi complex, GalCer can be sulfated to produce acidic GSL (Sulfatide). Incorporation of galactose to GlcCer yields lactosylceramide (LacCer), a common precursor for the base structures of the different GSL series described in Figure 1.

Most LacCer are further elongated at the Golgi lumen by a series of glycosyltransferases that define the composition of GSL in a cell by their expression and intracellular distribution. These enzymes are regulated at the transcriptional, translational or post-translational level [16-18]. Additional regulation occurs through the availability of the sugar nucleotides and precursor acceptors as different enzymes may compete for the same substrate. Furthermore, different GSL glycosyltransferases may associate to form functional "multiglycosyltransferase" complexes that ensure progression to the preferred end product without releasing intermediate structures [19].

Changes in GSL synthesis in tumors. Aberrant GSL glycosylation occurs frequently in tumors (see Figure 2 [2]). The changes may be due to incomplete synthesis of certain GSL with the accumulation of precursors [20]. Early branch point alterations in the normal biosynthetic pathway can thus affect the amount of one class of GSL structure and allow the dominance of another to emerge. Epigenetic changes diminish expression of specific transferases (e.g. $\mathrm{B}_{4} \mathrm{GalNAcT}_{2}$, $\mathrm{ST}_{3} \mathrm{Gal}_{6}, \mathrm{ST}_{6} \mathrm{GalNAc}_{6}$ and $\mathrm{GlNAc}_{6} \mathrm{ST}$ ) in gastrointestinal tumors, altering the enzymatic activity of the concert of transferases and thus causing the accumulation of sialyl Lewisx and sialyl Lewisa [21,22]. In addition, hypoxic conditions can increase the expression of HIF (hypoxia inducible factor), which induces the transcription of glycosyltransferases $\mathrm{FUT}_{7}$ and $\mathrm{ST}_{3} \mathrm{Gal}-1$ and transporter $\mathrm{UGT}_{1}$, also leading to sialyl Lewisx and sialyl Lewisa formation [23]. In adult Tcell leukemia, caused by Human T-cell Leukemia Virus type 1 (HTLV-1), the transcription of the $\mathrm{FUT}_{7}$ is constitutively activated by Tax protein (a viral molecule), increasing sialyl Lewisx synthesis [24].

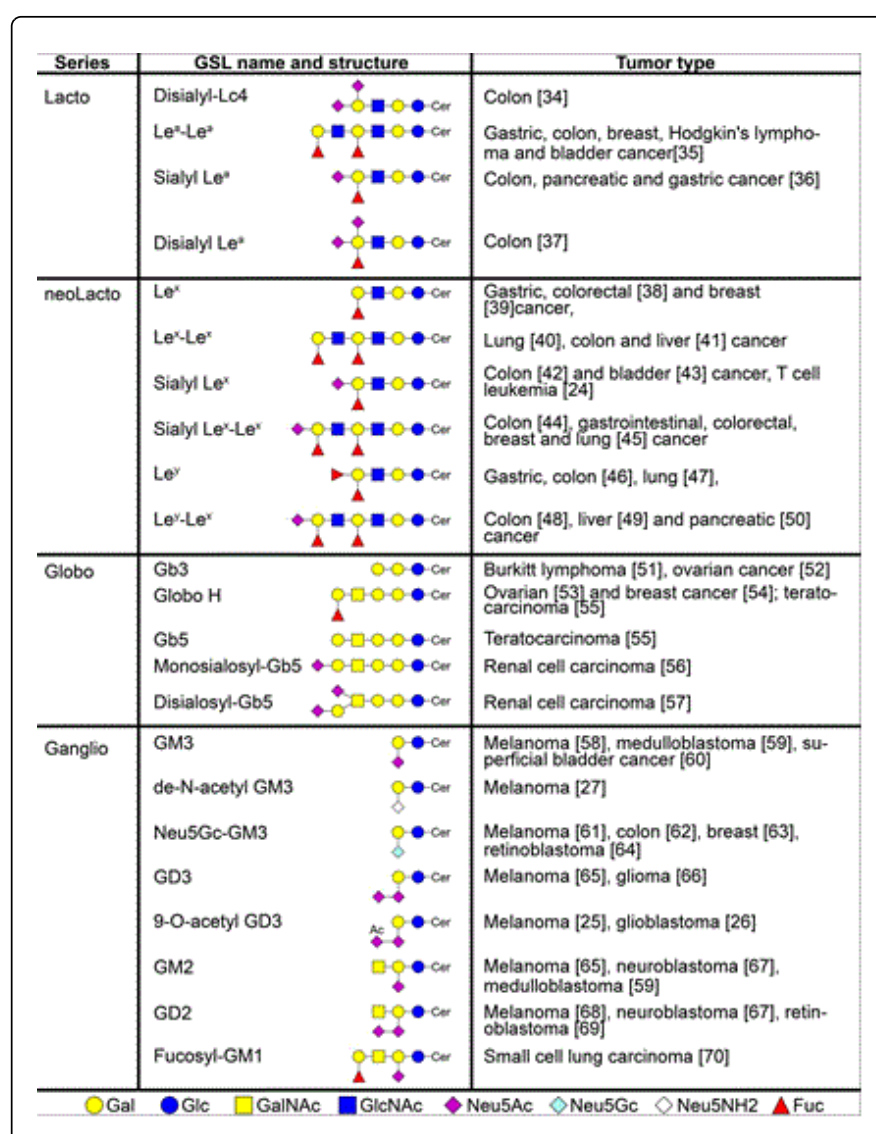

Figure 2: GSL molecules with altered expression in different types of cancer. Series, name and structure are listed for each GSL, along with the tumor type they are found to be altered.

Enhanced "neosynthesis" of GSL, which are minimal or absent in normal cells or tissues also leads to aberrant GSL in tumors [20]. Abnormal sialylation is a frequent alteration on tumor cells. For example, malignant melanomas have 9-O-acetylated $\mathrm{GD}_{3}$ instead of $\mathrm{GD}_{3}$ found in normal cells [25] and a critical ratio between $\mathrm{GD}_{3}$ and 9$\mathrm{O}$-acetyl $\mathrm{GD}_{3}$ on glioblastoma promotes tumor survival [26]. In fact, restoring $\mathrm{GD}_{3}$ by acetyl group cleavage reduces tumor cell viability by induction of mitochondrial-mediated apoptosis.

Another example of abnormal sialylation is represented by the loss of an acetyl group of $\mathrm{GM}_{3}$ (de-N-acetyl $\mathrm{GM}_{3}$ ) [27], leading to enhanced EGF-dependent tyrosine kinase activity of the epidermal growth factor (EGF) receptor while GM3 in normal cells inhibits EGFstimulated tyrosine phosphorylation of the EGF receptor [28]. In addition, de- $\mathrm{N}$-acetyl $\mathrm{GM}_{3}$ increases the expression and activation of urokinase-like plasminogen activator (uPA) and activates matrix metalloproteinase-2 in metastatic melanoma, thus stimulating cell migration and invasion [29]. 
Aberrant GSL glycosylation in tumors may also occur due to the increased use of recycling pathways. Although humans lack the enzyme to convert $\mathrm{N}$-acetylneuraminic acid (Neu5Ac) to $\mathrm{N}$ glycolylneuraminic acid [30], dietary uptake provides Neu5Gc through lysosomal sialidase activity on endocytosed Neu5Gc-bearing glycoconjugates. This free Neu5Gc is then transported into the cytosol, reactivated with cytidine triphosphate (CTP) in the nucleus [31], and preferentially utilized by tumors [32]. Thus, the usual Neu5Ac molecule is replaced by Neu5Gc, leading to the aberrant expression of Neu5Gc in tumors. This molecule, which differs from Neu5Ac by a single oxygen atom, has been shown to sustain low-grade chronic inflammation that can facilitate tumor progression through growthpromoting and angiogenic signals [33].

\section{GSL shedding and uptake}

Increased levels of aberrant GSL are present in patients with various tumors. The idea that tumors might shed GSL into the extracellular space dates back to an observation nearly 40 years ago in breast cancer patients who had elevated serum levels of sialic acid-containing GSL [71]. Portoukalian et al. later found that the same GSL shed by melanomas were also enriched in erythrocyte plasma membranes of melanoma patients [72]. These associative findings suggested a clinical relevance for dysregulated GSL synthesis and shedding. In fact, increased levels of circulating GD2 in patients with neuroblastoma at the time of diagnosis were correlated with faster disease progression and lower survival rate [73]. In addition, GD3 levels in sera from patients with different stages of astrocytomas and glioblastomas were proportionally higher with more aggressive World Health Organization histologic grade [66]. Similarly, serum fucosyl-GM1 levels in small cell lung carcinoma patients positively correlated with the presence of multiple site metastases [70]. Lastly, serum levels of total gangliosides correlated with clinical course in melanoma patients after immunotherapy with a therapeutic cancer vaccine [74].

Figure 3 summarizes the process of shedding and uptake. The physiologic significance of GSL shedding and uptake is unknown. By transferring molecules, GSL shedding provides a mechanism to alter diverse surface properties on donor and/or acceptor cells [75-79]. In tumors, GSL shedding occurs rapidly $(\approx 0.1$ to $0.5 \%$ of total cell GSL per hour $[59,67])$. Although the concentration of GSL in the extracellular milieu depends on the GSL pattern of the tumor (as seen for human malignant melanomas [80]), shorter lengths of the ceramide fatty acyl chain may determine the preferential shedding of various GSL by different tumor cells $[81,82]$ and also may influence their immunosuppressive activity.

In neuroblastoma patients, circulating $\mathrm{GD}_{2}$ is largely bound to serum lipoproteins, approximately $75 \%$ binding LDL [83]. Dual chamber culture experiments have documented cell to cell transfer of GSL shed from lymphoma [84] and medulloblastoma [85] cell lines to human fibroblasts. Interestingly, inhibitors of GSL synthesis diminish the shedding and transfer of potentially biologically active GSL from the tumor [85], and also reduced the ability of murine melanomas to form tumors [86].

Studies on ovarian carcinoma cell lines suggest GSL-containing membrane vesicle shedding originates in plasma membrane domains enriched in GSL and caveolin-1 [87]. However, the shed GSL can be found in different forms that include not only large complexes (membrane vesicles), but also micelles and monomers [88]. Analyses on the relative composition of GSL suggest they could also be shed from cell membranes via a mechanism of preferential release for some particular GSL components [82].

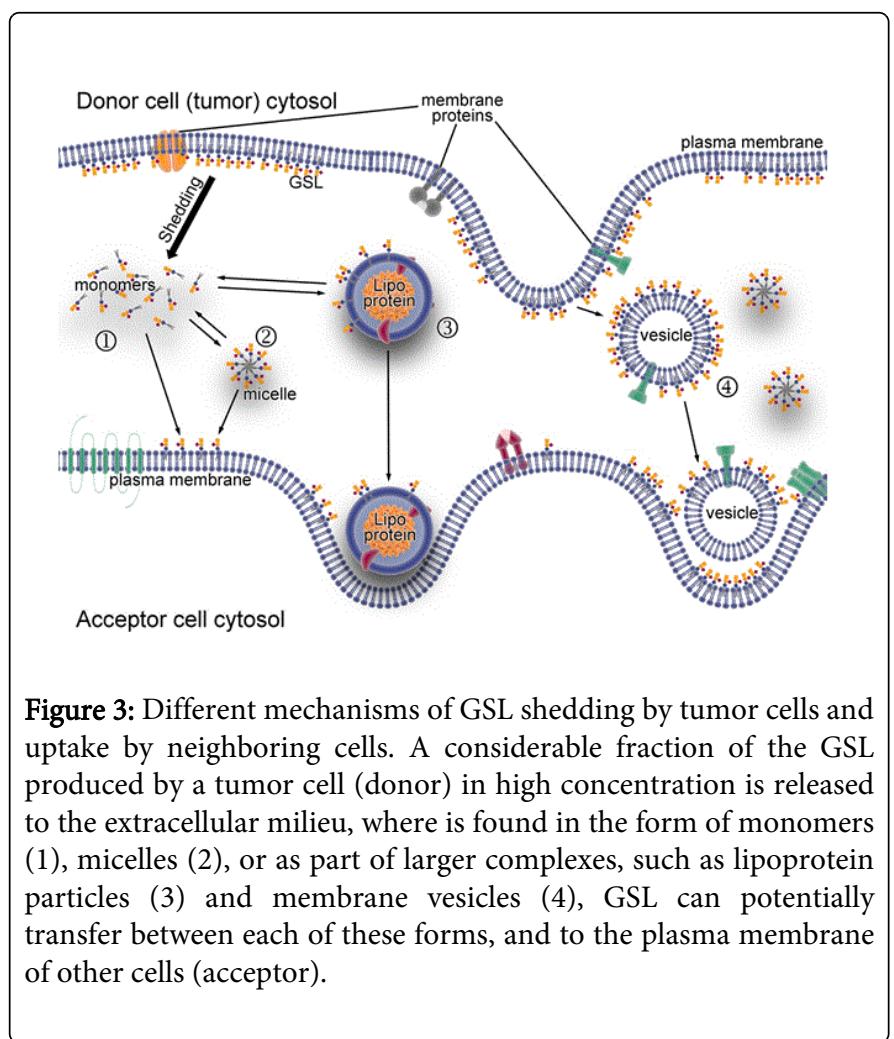

\section{Immunomodulatory mechanisms of GSL}

The advent of immunotherapies for cancer has resulted in durable clinical responses and confirmed that immune responses may prevent cancer progression [89]. Moreover, tumor-infiltrating immune cells correlate with a positive outcome in many types of cancer [90-93]. However, chronic inflammation is associated with cancer, and certain immune cells (e.g., $\mathrm{T}$ regulatory cells) are associated with disease progression [94]. To resolve this paradoxical relationship between cancer and the immune system, a current paradigm is referred to as immune editing [95]. Immune elimination of tumor cells selects for tumor cells that are poorly recognized, which may ultimately escape immune recognition when the tumor creates an immunosuppressive environment. Tumors may shed different GSL to create conditions for evading immune surveillance, leading to a favorable environment for tumor progression. The GSL shed by the tumor may alter the membrane composition of infiltrating immune cells and inhibit their function, allowing tumor escape.

Monocytes, macrophages, and dendritic cells (DC). Cells of the innate immune system, including monocytes, macrophages, and dendritic cells, control tumors by killing tumor cells directly, secreting inflammatory mediators that recruit and differentiate adaptive immune cells, and presenting tumor antigens to T cells [96-98]. However, the latter two (indirect) antitumor functions of innate immune cells are inhibited by GSL in general, and particularly by those altered GSL found on tumor cells (see Figure 4, parts "1" and "2").

Monocyte/macrophages. Monocytes exposed to bovine brain gangliosides [99], human brain gangliosides [100], or purified $\mathrm{GD}_{1 \mathrm{a}}$ 
[101] fail to stimulate antigen-specific lymphoproliferative responses. Gangliosides prevent up-regulation of the co-stimulatory molecule CD80, whereas expression of ICAM-1, LFA-3, HLA-DR, and CD86 is not affected. Accordingly, monocytes pre-incubated with $\mathrm{GD}_{1 \mathrm{a}}$ also show inhibition of CD80 up-regulation, down-regulation of CD40 and reduced IL-12 and TNF- $\alpha$ release in response to LPS stimulation [101], events that could be mediated by impeding NF- $\kappa B$ mobilization [102]. Moreover, previous exposure of monocytes to $\mathrm{GM}_{2}$ and $\mathrm{GM}_{3}$, or to $\mathrm{GM}_{1}$ and $\mathrm{GD}_{3}$, exhibit reduced $\mathrm{Fc}$ receptor expression and IL-1 production, respectively [103]. $\mathrm{GM}_{3}$, in particular, inhibits the VEGFinduced in vivo and in vitro expression of adhesion molecules (ICAM-1 and VCAM-1) on endothelium (in a mechanism mediated by activation of NF- $\kappa \mathrm{B}$ via AKT signaling), and reduces monocyte adhesion to endothelial cells [104]. All these events lead to impaired leukocyte recruitment to endothelial cells under inflammatory stimuli, ultimately resulting detrimental to an effective anti-tumor immune response.

Dendritic cells. Development and function of monocyte-derived $\mathrm{DC}$ can be affected by gangliosides including $\mathrm{GM}_{2}$ [105], $\mathrm{GD}_{1} \mathrm{a}$ [106], $\mathrm{GM}_{3}$ and $\mathrm{GD}_{3}$ [107] in vitro, suggesting GSL may influence DC differentiation in vivo. The presence of GM2 changes the morphology, adherence, and cell surface receptor expression of DC precursors. For example, $\mathrm{MHC}$ class II molecules, costimulatory molecules and $\mathrm{CD}_{116}$ (GM-CSF receptor) are significantly reduced, as well as their endocytic, chemotactic and T cell proliferation-inducing activities. DC preincubated with $\mathrm{GD}_{1}$ a poorly up-regulate costimulatory molecules and exhibit reduced IL-12 and increased IL-10 production when exposed to antigenic bacterial toxins [106]. Meanwhile, $\mathrm{GM}_{3}$ and $\mathrm{GD}_{3}$ strongly down-regulate $\mathrm{CD}_{1} \mathrm{a}, \mathrm{CD}_{54}, \mathrm{CD}_{80}$ and $\mathrm{CD}_{40}$ molecules, impair allostimulatory functions, reduce IL-12 and increase IL-10 production, and induce caspase 3-mediated apoptosis [107]. The mechanisms by which $\mathrm{GM}_{3}$ and $\mathrm{GD}_{3}$ induce apoptosis differ in that $\mathrm{GM}_{3}$ causes accumulation of sphingomyelinase-generated ceramides and $\mathrm{GD}_{3}{ }^{-}$ induced apoptosis is dependent on reactive oxygen species [108]. Although mature DC appear to be resistant to the $\mathrm{GM}_{2}$-mediated inhibitory effect, $\mathrm{GD}_{1}$ a-preincubated $\mathrm{DC}$ exhibit no $\mathrm{CD}_{80}$ upregulation, and also downregulate $\mathrm{CD}_{40}$, IL-12, TNF- $\alpha$ and IL- 6 in response to LPS [101]. These activated DC show evidence of NF- $\kappa B$ activation disruption, which may account for ganglioside interference with APC expression of costimulatory molecules and cytokine secretion. In summary, GSL dysregulation in tumors acts to prevent T cell recognition by interfering with various macrophage and DC functions.

B cells. B cells in the tumor environment may produce antitumor antibodies that target tumor for killing by effector cells, as well as present antigens to T cells. In vitro studies show that GM2 ganglioside inhibits spontaneous immunoglobulin production on isolated $\mathrm{B}$ cells, by inhibiting endogenous IL-10 and TNF- $\alpha$ production [109]. $\mathrm{GD}_{1 \mathrm{~b}}$ or $\mathrm{GT}_{1} \mathrm{~b}$ also can affect $\mathrm{B}$ cells by inhibiting spontaneous IgG, IgM and IgA production; however the effect is indirect in that treatment of $\mathrm{T}$ cells or isolated monocytes with $\mathrm{GD}_{1 \mathrm{~b}}$ or $\mathrm{GT}_{1 \mathrm{~b}}$ alters $\mathrm{T}$ cells and monocytes. $\mathrm{GD}_{1 \mathrm{~b}}$ caused decreased IL- 6 and IL-10 production from $\mathrm{CD}_{4} \mathrm{~T}$ cells [110]. $\mathrm{GT}_{1} \mathrm{~b}$ has a similar effect on monocytes [111]. When these ganglioside-treated $\mathrm{T}$ cells or monocytes are then co-cultured with $\mathrm{B}$ cells, antibody production is decreased. In contrast, $\mathrm{GQ}_{1 \mathrm{~b}}$ [112] and $\mathrm{GD}_{1 \mathrm{a}}$ [113] can counteract the effects of $\mathrm{GD}_{1 \mathrm{~b}}$ and $\mathrm{GT}_{1 \mathrm{~b}}$, respectively, and thus enhance Ig production by human PBMC. Meanwhile, $\mathrm{GM}_{2}$ and also $\mathrm{GM}_{3}$ gangliosides inhibit $\mathrm{B}$ cell production of IgG subclasses and IgM, with no effect on IgA subclasses [114]. Addition of TNF- $\alpha$ can counteract these inhibitions. Taken together, these studies show that GSL can negatively impact antitumor Ig production (see Figure 4, part " 3 "), but their effect on B cell antigen presentation has not been determined.

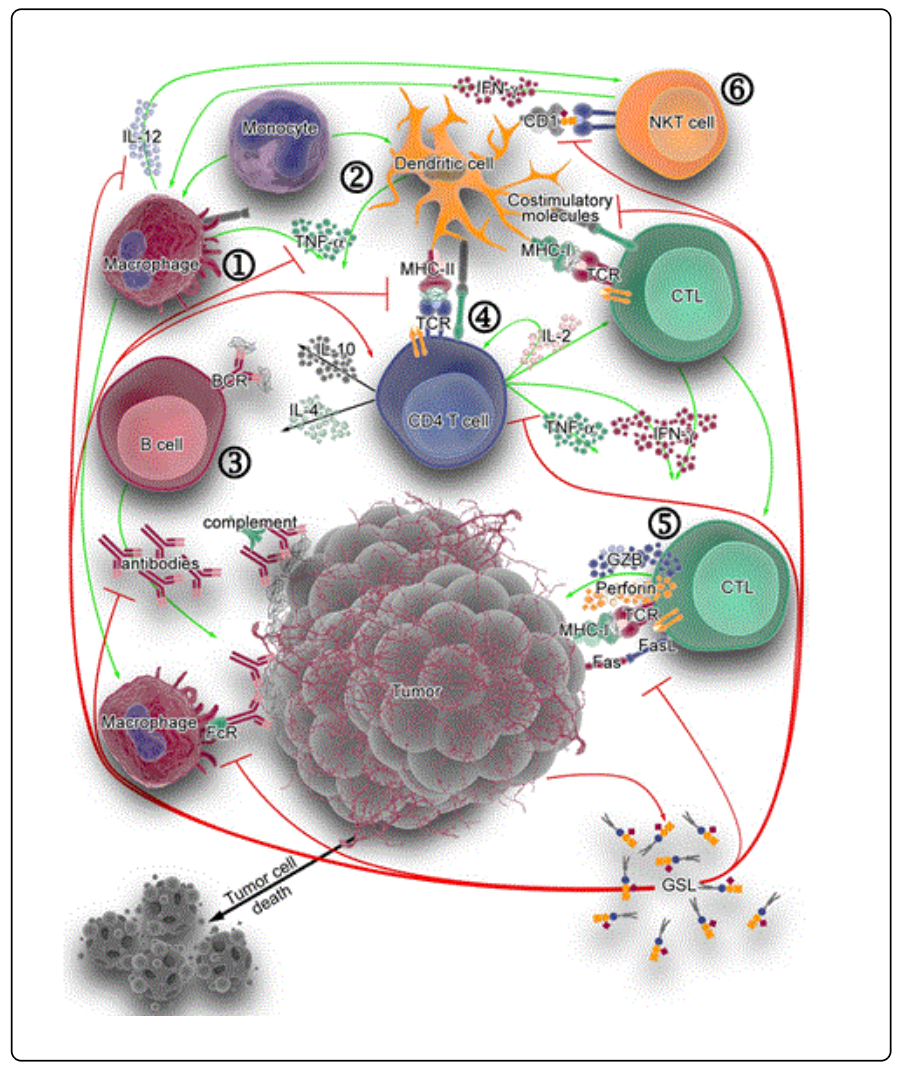

Figure 4: GSL modulate anti-tumor activity of immune cells. Different immune cells act concertedly on promoting tumor cell death through multiple mechanisms. Many of these mechanisms are influenced negatively by GSL shed from tumor cells. For example, GSL can affect the expression of costimulatory molecules and proinflammatory cytokine release from macrophages (1). In addition, GSL interferes with dendritic cell capabilities to promote antigen-specific $\mathrm{T}$ cell activation (2). The spontaneous antibody production on B cells (3) is also inhibited by GSL. Type $1 \mathrm{~T}$ cell responses driven by $\mathrm{CD} 4 \mathrm{~T}$ cells (4), including antigen-specific activation, production of IFN- $\gamma$ and IL-2-mediated T cell expansion are impaired, whereas type 2 responses are favored or not affected to the same extent. GSL affect negatively the formation and also the granule exocytosis-mediated cytotoxicity of antigen-specific CD8+ cytotoxic T cells (5). Various GSL have also been shown to prevent NKT cell activation (6). Green arrows represent actions performed by immune cells, whereas red lines indicate effects mediated by shed GSL. See main text for details.

CD4 T cells, CD8 cytotoxic T cells, NKT cells. T cells play an important role in anti-tumor immunity, as helper cells for antibody production and cell-mediated immune responses as well as effector cells for tumor killing [115].

CD4 helper T cells. Type-1 T cell responses (represented by IFN- $\gamma$ and IL-2-producing T cells) are essential for the induction of cytolytic, anti-tumor immunity [116] while type- $2 \mathrm{~T}$ cells producing IL-4, IL-6 and IL-10 are related to suppression of cytolytic activity [117]. In fact, 
cancer patients show increased type-2 cytokine production [118]. GSL influence $\mathrm{T}$ cell activation at numerous levels, including transcription of $\mathrm{T}$ helper cytokine genes, ligand-receptor binding of cytokines, antigen presentation, and $\mathrm{T}$ cell apoptosis (see Figure 4, part “4”). Rel/NF- $\mathrm{\kappa B}$ regulate transcription of a large number of genes involved in T-cell development, maturation and proliferation [119]. Gangliosides derived from renal cell carcinomas (RCC) inhibit NF-кB activity in T cells, reduce IL-2 and IFN- $\gamma$ expression [120] and increase apoptosis [121]. These changes are mediated by a decrease in the levels of RelA(p65), p50 and the antiapoptotic protein Bcl- $\mathrm{x}_{\mathrm{L}}$ (in a caspase dependent pathway), and can be impeded by blocking ganglioside synthesis [121].

When present during anti- $\mathrm{CD}_{3}$ antibody-induced activation of murine T cells, GT1b ganglioside reduces the levels of IFN- $\gamma$ and increases IL-4, compatible with a shift towards a type-2 response [122]. Whereas the IFN-K reduction occurs in both CD4+ and CD8+ cell populations, the IL-4 enhancement is observed only in CD4+ T cells. However, the effects on the production of these two cytokines appear to be independent of each other. Similarly, human T cells activated in the presence of (RCC)- or brain-derived gangliosides show inhibition of IFN- $\gamma$ (mRNA and protein) responses, apoptosis of activated T cells, but no influence on type- 2 cytokines IL-4, IL-5 and IL-10 $[123,124]$. These findings are correlated in vivo, where $\mathrm{T}$ cells from RCC patients display a greater level of apoptosis. Interestingly, most of the apoptotic cells are $\mathrm{GM}_{2}+\left(\mathrm{GD}_{2}+\right.$ or $\left.\mathrm{GD}_{3}+\right) \mathrm{T}$ cell populations, even though the mRNA expression levels for $\mathrm{GM}_{2}$ synthase are negligible [125]. Therefore, it is tempting to speculate that the ectopic presence of $\mathrm{GM}_{2}$ on apoptotic $\mathrm{T}$ cells is derived from the tumor, and that GM2 may be involved in triggering apoptosis. GSL-induced apoptosis is mediated by various mechanisms including reactive oxygen species, reduction of NF- $\mathrm{KB}$-dependent antiapoptotic protein expression levels, induction of cytochrome $\mathrm{c}$ release and activation of caspases 3, 8 and 9, occurring on activated but not resting $\mathrm{T}$ cells [125-127]. Although opposed effects for some of these type-2-promoting changes are observed using more complex gangliosides such as $\mathrm{GD}_{1 \mathrm{~b}}, \mathrm{GT}_{1 \mathrm{~b}}$ and $\mathrm{GQ}_{1 b}$ [128], this can be attributed to the usage of experimental conditions involving phytohemagglutinin (PHA)-stimulation of $\mathrm{T}$ cells. PHA engages multiple different glycosylated surface proteins, leading to activation of several, confounding different signaling pathways [129].

Antigen-specific activation of $\mathrm{T}$ cells requires the active participation of antigen presenting cells (APC) such as DC, macrophages and certain $\mathrm{B}$ cells, whose functions are affected by certain GSL. Ganglioside pretreatment of DC reduces antigen presentation to naïve $\mathrm{T}$ cells, leading to diminished proliferation and, accordingly, fewer IFN- $\gamma$-producing cells (type-1) and IL-4-producing cells (type-2) [106]. Among the molecular events implicated in antigen-specific activation of T cells, binding of IL-2 to its cell surface receptor (IL-2R) on $\mathrm{T}$ cells constitutes a critical step, in order to proceed through the $G_{1}$ checkpoint of the cell cycle and trigger DNA synthesis and replication [130]. Brain-derived gangliosides can also interfere with these events by blocking IL-2 gene transcription in activated human $\mathrm{T}$ cells [124], and preventing phosphorylation of retinoblastoma protein ( $\mathrm{RB}$, a regulator of cell cycle progression) [124]. Moreover, mixtures of mono-, di- and tri-sialo gangliosides inhibit IL-2-stimulated proliferation of IL-2-dependent cell lines, CTLL-2 and HT-2 [131]. This dose-dependent effect occurs through direct binding of a lectin-like site on IL-2 to gangliosides, thus creating a competitive inhibition for IL-2 binding to IL-2R. A similar mechanism of direct cytokine-ganglioside interaction is thought to explain ganglioside-mediated inhibition of IL-4-stimulated helper T cell proliferation [132].

CD8 cytotoxic T cells. Cytotoxic T cells (CTL) mediate antitumor immunity by directly killing tumor cells [133]. The expansion of CTL is affected by GSL exposure. When splenocytes from mice immunized with FBL-3 erythroleukemia cells are rechallenged in vitro with irradiated FBL-3 tumor in the presence of gangliosides shed by these erythroleukemia cells, the tumor-specific response and the generation of CTL are suppressed. These GSL can impair responses to a secondary challenge as well (measured as reduced lymph node mass, cell number and proliferation), when coinjected in vivo with a primary FBL-3 cell immunization in mice [134]. An inhibition of the increase of draining lymph node $\mathrm{T}$ cells $(\mathrm{CD} 3+)$ is also observed [134]. In addition, gangliosides can also influence the function of CTL (Figure 4, part " 5 "). Tumor-derived and individual highly purified gangliosides inhibit granule exocytosis-mediated cytotoxicity of alloantigen-specific and polyclonal CD8+ CTL [135]. Interestingly, they have no influence on lytic molecule expression, nor do they interfere with target cell recognition. Instead, they inhibit lytic granule release from CD8+ CTL by preventing TCR-induced lytic granule polarization, immunological synapse accumulation, and exocytosis [135].

Natural Killer T cells. Another cell type for which antitumor activity has been demonstrated is natural killer T (NKT) cells (Figure 4, part "6"). These $\mathrm{T}$ cells recognize a variety of both exogenous and endogenous lipid and glycolipid antigens presented in CD1 molecules, cell surface glycoproteins structurally resembling to MHC I molecules [136]. Upon activation, NKT cells produce cytokines that can influence immune responses against tumors [137]. Although $\mathrm{GD}_{3}$ can induce a $\mathrm{GD}_{3}$-reactive $\mathrm{NKT}$ cell response in melanoma [138], it is found to prevent NKT cell activation in ovarian cancer [139]. $\mathrm{GM}_{3}$ can also act as an inhibitory ligand for the NKT cell response to $\mathrm{GD}_{3}$ [140]. Asialo- $\mathrm{GM}_{2}$, shed from the murine $\mathrm{T}$ cell lymphoma line L5178Y-R, is another glycosphingolipid that prevents NKT cell recognition [141].

\section{Concluding Remarks}

GSL are components of the external leaflet of plasma membranes and, as such, participate in numerous events of cellular interaction. Distinct GSL structures are generated through a series of intricate biosynthetic processes in the Golgi that are fine-tuned by several mechanisms. Tumors present several alterations in their GSL content. Equally important, GSL are actively released from the membrane of tumor cells and can bind immune cells to influence their function through multiple mechanisms, having a strong impact on impairing antitumor immunity and allowing tumor immune escape.

As auto-antigens present on normal cells at low levels, GSL are poorly immunogenic. Over several years, different strategies aimed at promoting anti-ganglioside immune responses have been studied, with disparate success. Besides the direct vaccination with GSL conjugated to adjuvants such as keyhole limpet haemocyanin [142], other approaches like anti-idiotypic antibodies [143], chimeric T cells [144], genetically-engineered antibodies [145] and GSL-mimicking peptides [146] have been assayed. These various strategies have been extensively reviewed elsewere $[147,148]$.

Successful immune cell- or antibody-responses again GSL have the ability not only to target and kill tumor cells, but also to reduce the bioavailability of these molecules. Related to this concept, promising use of GSL synthesis inhibition in animal models of cancer [149-152] 
supports the notion that targeting GSL biosynthesis, for example with N-butyldeoxynojirimycin (a clinically approved inhibitor for glucosylceramide synthase), could be further explored in human cancer as a therapeutic approach, aiming to intervene on GSL metabolism of tumor cells and modulate GSL shedding, thus lessening the immunomodulatory effects of GSL.

\section{Acknowledgements}

This work was supported by National Institutes of Health $\left(\mathrm{AR}_{59126}\right)$ and the Joseph B. Gould Foundation.

\section{References}

1. Hakomori S (1981) Glycosphingolipids in cellular interaction, differentiation and oncogenesis. Annu Rev Biochem 50: 733-764.

2. Hakomori S (1989) Aberrant glycosylation in tumors and tumorassociated carbohydrate antigens. Adv Cancer Res 52: 257-331.

3. Ledeen RW, Yu RK (1982) Gangliosides: structure, isolation, and analysis. Methods Enzymol 83: 139-91.

4. Yu RK, Yanagisawa M, Ariga T (2007) Glycosphingolipid structures, in Comprehensive glycoscience, from chemistry to system biology. (1st ed.), Elsevier, Oxford.

5. Gabius HJ (2008) Glycans: bioactive signals decoded by lectins. Biochem Soc Trans 36: 1491-6.

6. Jackman N, Ishii A, Bansal R (2009) Oligodendrocyte development and myelin biogenesis: parsing out the roles of glycosphingolipids. Physiology 24: 290-7.

7. Simons K, Ikonen E (1997) Functional rafts in cell membranes. Nature 387: $569-572$

8. Dabelsteen E, Mandel U, Clausen H (1991) Cell surface carbohydrates are markers of differentiation in human oral epithelium. Crit Rev Oral Biol Med 2: 493-507.

9. Fish RG (1996) Role of gangliosides in tumour progression: a molecular target for cancer therapy? Med Hypotheses 46: 140-144.

10. Hakomori S (1990) Bifunctional role of glycosphingolipids. Modulators for transmembrane signaling and mediators for cellular interactions. J Biol Chem 265: 18713-18716.

11. Kojima N, Hakomori S (1989) Specific interaction between gangliotriaosylceramide (Gg3) and sialosyllactosylceramide (GM3) as a basis for specific cellular recognition between lymphoma and melanoma cells. J Biol Chem 264: 20159-62.

12. LetiniÄ K, Heffer-Lauc M, Rosner H, KostoviÄ K (1998) C-pathway polysialogangliosides are transiently expressed in the human cerebrum during fetal development. Neuroscience 86: 1-5.

13. Miura R, Ethell IM, Yamaguchi Y (2001) Carbohydrate-protein interactions between HNK-1-reactive sulfoglucuronyl glycolipids and the proteoglycan lectin domain mediate neuronal cell adhesion and neurite outgrowth. J Neurochem 76: 413-424.

14. Singh AK, Harrison SH, Schoeniger JS (2000) Gangliosides as receptors for biological toxins: development of sensitive fluoroimmunoassays using ganglioside-bearing liposomes. Anal Chem 72: 6019-6024.

15. Hakomori S (1983) Glycosphingolipids in cellular interaction, differentiation, and oncogenesis, in Sphingolipid Biochemistry. (1st ed.), Springer US.

16. Crespo PM, Silvestre DC, Gil GA, Maccioni HJ, Daniotti JL, et al. (2008) c-Fos activates glucosylceramide synthase and glycolipid synthesis in PC12 cells. J Biol Chem 283: 31163-31171.

17. Maccioni HJ (2007) Glycosylation of glycolipids in the Golgi complex. J Neurochem 103 Suppl 1: 81-90.

18. Uliana AS, Crespo PM, Martina JA, Daniotti JL, Maccioni HJ (2006) Modulation of GalT1 and SialT1 sub-Golgi localization by SialT2 expression reveals an organellar level of glycolipid synthesis control. J Biol Chem 281: 32852-32860.
19. Giraudo CG, Daniotti JL, Maccioni HJ (2001) Physical and functional association of glycolipid $\mathrm{N}$-acetyl-galactosaminyl and galactosyl transferases in the Golgi apparatus. Proc Natl Acad Sci U S A 98: 1625-1630.

20. Hakomori S (2000) Traveling for the glycosphingolipid path. Glycoconj J 17: 627-647.

21. Kannagi R (2004) Molecular mechanism for cancer-associated induction of sialyl Lewis $\mathrm{X}$ and sialyl Lewis A expression-The Warburg effect revisited. Glycoconj J 20: 353-364.

22. Kawamura Y, Toyota M, Kawashima R, Hagiwara T, Suzuki H, et al. (2008) DNA hypermethylation contributes to incomplete synthesis of carbohydrate determinants in gastrointestinal cancer. Gastroenterology 135: 142-151.

23. Koike T, Kimura N, Miyazaki K, Yabuta T, Kumamoto K, et al. (2004) Hypoxia induces adhesion molecules on cancer cells: A missing link between Warburg effect and induction of selectin-ligand carbohydrates. Proc Natl Acad Sci U S A 101: 8132-8137.

24. Hiraiwa N, Hiraiwa M, Kannagi R (1997) Human T-cell leukemia virus-1 encoded Tax protein transactivates alpha 1-->3 fucosyltransferase Fuc-T VII, which synthesizes sialyl Lewis $\mathrm{X}$, a selectin ligand expressed on adult T-cell leukemia cells. Biochem Biophys Res Commun 231: 183-186.

25. Cheresh DA, Reisfeld RA, Varki AP (1984) O-acetylation of disialoganglioside GD3 by human melanoma cells creates a unique antigenic determinant. Science 225: 844-846.

26. Birks SM, Danquah JO, King L, Vlasak R, Gorecki DC, et al. (2011) Targeting the GD3 acetylation pathway selectively induces apoptosis in glioblastoma. Neuro Oncol 13: 950-960.

27. Chammas R, Sonnenburg JL, Watson NE, Tai T, Farquhar MG, et al (1999) De-N-acetyl-gangliosides in humans: unusual subcellular distribution of a novel tumor antigen. Cancer Res 59: 1337-1346.

28. Hanai N, Dohi T, Nores GA, Hakomori S (1988) A novel ganglioside, de$\mathrm{N}$-acetyl-GM3 (II3NeuNH2LacCer), acting as a strong promoter for epidermal growth factor receptor kinase and as a stimulator for cell growth. J Biol Chem 263: 6296-6301.

29. Liu JW, Sun P, Yan Q, Paller AS, Gerami P, et al. (2009) De-N-acetyl GM3 promotes melanoma cell migration and invasion through urokinase plasminogen activator receptor signaling-dependent MMP-2 activation. Cancer Res 69: 8662-8669.

30. Chou HH, Takematsu H, Diaz S, Iber J, Nickerson E, et al. (1998) A mutation in human CMP-sialic acid hydroxylase occurred after the Homo-Pan divergence. Proc Natl Acad Sci U S A 95: 11751-11756.

31. Bardor M, Nguyen DH, Diaz S, Varki A (2005) Mechanism of uptake and incorporation of the non-human sialic acid N-glycolylneuraminic acid into human cells. J Biol Chem 280: 4228-4237.

32. Gabri MR, Otero LL, Gomez DE, Alonso DF (2009) Exogenous incorporation of neugc-rich mucin augments n-glycolyl sialic acid content and promotes malignant phenotype in mouse tumor cell lines. Journal of experimental \& clinical cancer research : CR 28: 146.

33. Hedlund M, Padler-Karavani V, Varki NM, Varki A (2008) Evidence for a human-specific mechanism for diet and antibody-mediated inflammation in carcinoma progression. Proc Natl Acad Sci U S A 105: 18936-18941.

34. Fukushi Y, Nudelman E, Levery SB, Higuchi T, Hakomori S (1986) A novel disialoganglioside (IV3NeuAcIII6NeuAcLc4) of human adenocarcinoma and the monoclonal antibody (FH9) defining this disialosyl structure. Biochemistry 25: 2859-2866.

35. Stroud MR, Levery SB, Nudelman ED, Salyan ME, Towell JA, et al. (1991) Extended type 1 chain glycosphingolipids: dimeric Lea (IIIVV4Fuc2Lc6) as human tumor-associated antigen. J Biol Chem 266: 8439-8446.

36. Magnani JL, Nilsson B, Brockhaus M, Zopf D, Steplewski Z, et al. (1982) A monoclonal antibody-defined antigen associated with gastrointestinal cancer is a ganglioside containing sialylated lacto-N-fucopentaose II. J Biol Chem 257: 14365-14369.

37. Nudelman E, Fukushi Y, Levery SB, Higuchi T, Hakomori S (1986) Novel fucolipids of human adenocarcinoma: disialosyl Lea antigen 
(III4FucIII6NeuAcIV3NeuAcLc4) of human colonic adenocarcinoma and the monoclonal antibody (FH7) defining this structure. J Biol Chem 261: 5487-5495

38. Hakomori S, Nudelman E, Levery S, Solter D, Knowles BB (1981) The hapten structure of a developmentally regulated glycolipid antigen (SSEA-1) isolated from human erythrocytes and adenocarcinoma: A preliminary note. Biochem Biophys Res Commun 100: 1578-1586.

39. Koh YW, Lee HJ, Ahn JH, Lee JW, Gong G (2013) Expression of Lewis X is associated with poor prognosis in triple-negative breast cancer. Am J Clin Pathol 139: 746-753.

40. Holmes EH, Ostrander GK, Hakomori S (1985) Enzymatic basis for the accumulation of glycolipids with $\mathrm{X}$ and dimeric $\mathrm{X}$ determinants in human lung cancer cells (NCI-H69). J Biol Chem 260: 7619-7627.

41. Hakomori S, Nudelman E, Levery SB, Kannagi R (1984) Novel fucolipids accumulating in human adenocarcinoma. I. Glycolipids with di- or trifucosylated type 2 chain. J Biol Chem 259: 4672-4680.

42. Levery SB, Nudelman E, Kannagi R, Symington FW, Andersen NH, et al. (1988) 1H-n.m.r. analysis of type-2 chain lacto-gangliosides. Confirmation of structure of a novel cancer-associated fucoganglioside, ?-NeuAc-(2?6)-?-D-Galp-(1?4)-?-D-GlcpNAc-(1?3)-? D-Galp-(1?4)-[?-L-Fucp-(1?3)]-?-D-GlcpNAc-(1?3)-?-D-Galp-(1?4)-?D-Glcp-(1?1)-Cer (VI6NeuAcIII3FucnLc6Cer). Carbohydr Res 178: 121-144.

43. Numahata K, Satoh M, Handa K, Saito S, Ohyama C, et al. (2002) Sialosyl-Le(x) expression defines invasive and metastatic properties of bladder carcinoma. Cancer 94: 673-685.

44. Fukushi Y, Nudelman E, Levery SB, Hakomori S, Rauvala H (1984) Novel fucolipids accumulating in human adenocarcinoma. III. A hybridoma antibody (FH6) defining a human cancer-associated difucoganglioside (VI3NeuAcV3III3Fuc2nLc6). J Biol Chem 259: 10511-10517.

45. Fukushi Y, Kannagi R, Hakomori S, Shepard T, Kulander BG, et al. (1985) Location and distribution of difucoganglioside (VI3NeuAcV3III3Fuc2nLc6) in normal and tumor tissues defined by its monoclonal antibody FH6. Cancer Res 45: 3711-3717.

46. Abe K, McKibbin JM, Hakomori S (1983) The monoclonal antibody directed to difucosylated type 2 chain (Fuc alpha 1 leads to $2 \mathrm{Gal}$ beta 1 leads to 4[Fuc alpha 1 leads to 3]GlcNAc; Y Determinant). J Biol Chem 258: 11793-11797.

47. Miyake M, Zenita K, Tanaka O, Okada Y, Kannagi R (1988) Stagespecific expression of SSEA-1-related antigens in the developing lung of human embryos and its relation to the distribution of these antigens in lung cancers. Cancer Res 48: 7150-7158.

48. Kaizu T, Levery SB, Nudelman E, Stenkamp RE, Hakomori S (1986) Novel fucolipids of human adenocarcinoma: monoclonal antibody specific for trifucosyl Ley (III3FucV3FucVI2FucnLc6) and a possible three-dimensional epitope structure. J Biol Chem 261: 11254-11258.

49. Levery SB, Nudelman ED, Andersen NH, Hakomori S (1986) 1H-n.m.r. analysis of glycolipids possessing mono- and multi-meric $\mathrm{X}$ and $\mathrm{Y}$ haptens: characterization of two novel extended $\mathrm{Y}$ structures from human adenocarcinoma. Carbohydr Res 151: 311-328.

50. Kim YS, Itzkowitz SH, Yuan M, Chung Y, Satake K, et al. (1988) Lex and Ley antigen expression in human pancreatic cancer. Cancer Res 48: 475-482.

51. Nudelman E, Kannagi R, Hakomori S, Parsons M, Lipinski M, et al. (1983) A glycolipid antigen associated with Burkitt lymphoma defined by a monoclonal antibody. Science 220: 509-511.

52. Farkas-Himsley H, Hill R, Rosen B, Arab S, Lingwood CA (1995) The bacterial colicin active against tumor cells in vitro and in vivo is verotoxin 1. Proc Natl Acad Sci U S A 92: 6996-7000.

53. Zhang S, Cordon-Cardo C, Zhang HS, Reuter VE, Adluri S, et al. (1997) Selection of tumor antigens as targets for immune attack using immunohistochemistry: I. Focus on gangliosides. Int J Cancer 73: 42-49.

54. Bremer EG, Levery SB, Sonnino S, Ghidoni R, Canevari S, et al. (1984) Characterization of a glycosphingolipid antigen defined by the monoclonal antibody MBr1 expressed in normal and neoplastic epithelial cells of human mammary gland. J Biol Chem 259: 14773-14777.

55. Kannagi R, Levery SB, Ishigami F, Hakomori S, Shevinsky LH, et al. (1983) New globoseries glycosphingolipids in human teratocarcinoma reactive with the monoclonal antibody directed to a developmentally regulated antigen, stage-specific embryonic antigen 3. J Biol Chem 258: 8934-8942.

56. Saito S, Aoki H, Ito A, Ueno S, Wada T, et al. (2003) Human alpha2,3sialyltransferase (ST3Gal II) is a stage-specific embryonic antigen-4 synthase. J Biol Chem 278: 26474-26479.

57. Satoh M, Handa K, Saito S, Tokuyama S, Ito A, et al. (1996) Disialosyl galactosylgloboside as an adhesion molecule expressed on renal cell carcinoma and its relationship to metastatic potential. Cancer Res 56: 1932-1938.

58. Hersey P, Jamal O, Henderson C, Zardawi I, D'Alessandro G (1988) Expression of the gangliosides GM3, GD3 and GD2 in tissue sections of normal skin, naevi, primary and metastatic melanoma. Int J Cancer 41: 336-343.

59. Chang F, Li R, Ladisch S (1997) Shedding of gangliosides by human medulloblastoma cells. Exp Cell Res 234: 341-346.

60. Kawamura S, Ohyama C, Watanabe R, Satoh M, Saito S, et al. (2001) Glycolipid composition in bladder tumor: a crucial role of GM3 ganglioside in tumor invasion. Int J Cancer 94: 343-347.

61. Malykh YN, Schauer R, Shaw L (2001) N-Glycolylneuraminic acid in human tumours. Biochimie 83: 623-634.

62. Higashi H, Nishi Y, Fukui Y, Ikuta K, Ueda S, et al. (1984) Tumorassociated expression of glycosphingolipid Hanganutziu-Deicher antigen in human cancers. Gann 75: 1025-1029.

63. Marquina G, Waki H, Fernandez LE, Kon K, Carr A, et al. (1996) Gangliosides expressed in human breast cancer. Cancer Res 56: 5165-5171.

64. Higashi H, Sasabe T, Fukui Y, Maru M, Kato S (1988) Detection of gangliosides as $\mathrm{N}$-glycolylneuraminic acid-specific tumor-associated Hanganutziu-Deicher antigen in human retinoblastoma cells. Jpn J Cancer Res 79: 952-956.

65. Tsuchida T, Saxton RE, Morton DL, Irie RF (1987) Gangliosides of human melanoma. J Natl Cancer Inst 78: 45-54.

66. Nakamura O, Iwamori M, Matsutani M, Takakura K (1991) Ganglioside GD3 shedding by human gliomas. Acta Neurochir (Wien) 109: 34-36.

67. Li RX, Ladisch S (1991) Shedding of human neuroblastoma gangliosides. Biochim Biophys Acta 1083: 57-64.

68. Portoukalian J, Zwingelstein G, Doré JF (1979) Lipid composition of human malignant melanoma tumors at various levels of malignant growth. Eur J Biochem 94: 19-23.

69. Portoukalian J, David MJ, Gain P, Richard M (1993) Shedding of GD2 ganglioside in patients with retinoblastoma. Int J Cancer 53: 948-951.

70. Vangsted A, Drivsholm L, Andersen E, Pallesen T, Zeuthen J, et al. (1994) New serum markers for small-cell lung cancer. I. The ganglioside fucosyl-GM1. Cancer Detect Prev 18: 221-229.

71. Kloppel TM, Keenan TW, Freeman MJ, Morré DJ (1977) Glycolipidbound sialic acid in serum: increased levels in mice and humans bearing mammary carcinomas. Proc Natl Acad Sci U S A 74: 3011-3013.

72. Portoukalian J, Zwingelstein G, Abdul-Malak N, Doré JF (1978) Alteration of gangliosides in plasma and red cells of humans bearing melanoma tumors. Biochem Biophys Res Commun 85: 916-920.

73. Valentino L, Moss T, Olson E, Wang HJ, Elashoff R, et al. (1990) Shed tumor gangliosides and progression of human neuroblastoma. Blood 75: 1564-1567.

74. Ravindranath MH, Hsueh EC, Verma M, Ye W, Morton DL (2003) Serum total ganglioside level correlates with clinical course in melanoma patients after immunotherapy with therapeutic cancer vaccine. J Immunother 26: 277-285.

75. Rusnati M, Urbinati C, Tanghetti E, Dell'Era P, Lortat-Jacob H, et al. (2002) Cell membrane GM1 ganglioside is a functional coreceptor for fibroblast growth factor 2. Proc Natl Acad Sci U S A 99: 4367-4372. 
76. Simons M, Friedrichson T, Schulz JB, Pitto M, Masserini M, et al. (1999) Exogenous administration of gangliosides displaces GPI-anchored proteins from lipid microdomains in living cells. Mol Biol Cell 10: 3187-3196.

77. Crespo PM, Zurita AR, Daniotti JL (2002) Effect of gangliosides on the distribution of a glycosylphosphatidylinositol-anchored protein in plasma membrane from Chinese hamster ovary-K1 cells. J Biol Chem 277: 44731-44739.

78. Brodsky V, Zvezdina N, Nechaeva N, Novikova T, Gvasava I, et al. (2003) Loss of hepatocyte co-operative activity after inhibition of ganglioside GM1 synthesis and shedding. Cell Biol Int 27: 935-942.

79. Brodsky VY, Nechaeva NV, Zvezdina ND, Novikova TE, Gvasava IG, et al. (2000) Ganglioside-mediated metabolic synchronization of protein synthesis activity in cultured hepatocytes. Cell Biol Int 24: 211-222.

80. Bernhard H, Meyer zum Büschenfelde KH, Dippold WG (1989) Ganglioside GD3 shedding by human malignant melanoma cells. Int J Cancer 44: 155-160.

81. Ladisch S, Li R, Olson E (1994) Ceramide structure predicts tumor ganglioside immunosuppressive activity. Proc Natl Acad Sci U S A 91: 1974-1978.

82. Young WW Jr, Borgman CA, Wolock DM (1986) Modes of shedding of glycosphingolipids from mouse lymphoma cells. J Biol Chem 261: 2279-2283.

83. Valentino LA, Ladisch S (1992) Localization of shed human tumor gangliosides: association with serum lipoproteins. Cancer Res 52: 810-814.

84. Olshefski R, Ladisch S (1996) Intercellular transfer of shed tumor cell gangliosides. FEBS Lett 386: 11-14.

85. Olshefski R, Ladisch S (1998) Synthesis, shedding, and intercellular transfer of human medulloblastoma gangliosides: abrogation by a new inhibitor of glucosylceramide synthase. J Neurochem 70: 467-472.

86. Deng W, Li R, Ladisch S (2000) Influence of cellular ganglioside depletion on tumor formation. J Natl Cancer Inst 92: 912-917.

87. Dolo V, Li R, Dillinger M, Flati S, Manela J, et al. (2000) Enrichment and localization of ganglioside $\mathrm{G}(\mathrm{D} 3)$ and caveolin-1 in shed tumor cell membrane vesicles. Biochim Biophys Acta 1486: 265-274.

88. Kong Y, Li R, Ladisch S (1998) Natural forms of shed tumor gangliosides. Biochim Biophys Acta 1394: 43-56.

89. Smyth MJ, Dunn GP, Schreiber RD (2006) Cancer immunosurveillance and immunoediting: the roles of immunity in suppressing tumor development and shaping tumor immunogenicity. Adv Immunol 90: 1-50.

90. Bindea G, Mlecnik B, Tosolini M, Kirilovsky A, Waldner M, et al. (2013) Spatiotemporal dynamics of intratumoral immune cells reveal the immune landscape in human cancer. Immunity 39: 782-795.

91. Erdag G, Schaefer JT, Smolkin ME, Deacon DH, Shea SM, et al. (2012) Immunotype and immunohistologic characteristics of tumor-infiltrating immune cells are associated with clinical outcome in metastatic melanoma. Cancer Res 72: 1070-1080.

92. de Kruijf EM, Engels CC, van de Water W, Bastiaannet E, Smit VT, et al. (2013) Tumor immune subtypes distinguish tumor subclasses with clinical implications in breast cancer patients. Breast Cancer Res Treat 142: 355-364.

93. Gooden MJ, de Bock GH, Leffers N, Daemen T, Nijman HW (2011) The prognostic influence of tumour-infiltrating lymphocytes in cancer: a systematic review with meta-analysis. Br J Cancer 105: 93-103.

94. Yu P, Fu YX (2006) Tumor-infiltrating T lymphocytes: friends or foes? Lab Invest 86: 231-245.

95. Kim R, Emi M, Tanabe K (2007) Cancer immunoediting from immune surveillance to immune escape. Immunology 121: 1-14.

96. Andreesen R, Osterholz J, Bross KJ, Schulz A, Luckenbach GA, et al. (1983) Cytotoxic effector cell function at different stages of human monocyte-macrophage maturation. Cancer Res 43: 5931-5936.

97. Lefebvre M-L, Krause SW, Salcedo M, Nardin A (2006) Ex vivo-activated human macrophages kill chronic lymphocytic leukemia cells in the presence of rituximab: mechanism of antibody-dependent cellular cytotoxicity and impact of human serum. J Immunother 29: 388-397.

98. Hume DA (2008) Macrophages as APC and the dendritic cell myth. J Immunol 181: 5829-5835.

99. Ladisch S, Ulsh L, Gillard B, Wong C (1984) Modulation of the immune response by gangliosides. Inhibition of adherent monocyte accessory function in vitro. J Clin Invest 74: 2074-2081.

100. Heitger A, Ladisch S (1996) Gangliosides block antigen presentation by human monocytes. Biochim Biophys Acta 1303: 161-168.

101. Caldwell S, Heitger A, Shen W, Liu Y, Taylor B, et al. (2003) Mechanisms of ganglioside inhibition of APC function. J Immunol 171: 1676-1683.

102. Ziegler-Heitbrock HW, Käfferlein E, Haas JG, Meyer N, Ströbel M, et al. (1992) Gangliosides suppress tumor necrosis factor production in human monocytes. J Immunol 148: 1753-1758.

103. Hoon DS, Jung T, Naungayan J, Cochran AJ, Morton DL, et al. (1989) Modulation of human macrophage functions by gangliosides. Immunol Lett 20: 269-275.

104. Kim SJ, Chung TW, Choi HJ, Jin UH, Ha KT, et al. (2014) Monosialic ganglioside GM3 specifically suppresses the monocyte adhesion to endothelial cells for inflammation. Int J Biochem Cell Biol 46: 32-38.

105. Wölfl M, Batten WY, Posovszky C, Bernhard H, Berthold F (2002) Gangliosides inhibit the development from monocytes to dendritic cells. Clin Exp Immunol 130: 441-448.

106. Shen W, Falahati R, Stark R, Leitenberg D, Ladisch S (2005) Modulation of CD4 Th cell differentiation by ganglioside GD1a in vitro. J Immunol 175: 4927-4934.

107. Péguet-Navarro J, Sportouch M, Popa I, Berthier O, Schmitt D, et al. (2003) Gangliosides from human melanoma tumors impair dendritic cell differentiation from monocytes and induce their apoptosis. J Immunol 170: 3488-3494.

108. Bennaceur K, Popa I, Chapman JA, Migdal C, Péguet-Navarro J, et al. (2009) Different mechanisms are involved in apoptosis induced by melanoma gangliosides on human monocyte-derived dendritic cells. Glycobiology 19: 576-582.

109. Kimata H, Yoshida A (1996) Inhibition of spontaneous immunoglobulin production by ganglioside GM2 in human B cells. Clin Immunol Immunopathol 79: 197-202.

110. Kanda N, Tamaki K (1999) Ganglioside GD1b suppresses immunoglobulin production by human peripheral blood mononuclear cells. Exp Hematol 27: 1487-1493.

111. Kanda N, Tamaki K (1999) Ganglioside GT1b suppresses immunoglobulin production by human peripheral blood mononuclear cells. Immunology 96: 628-633.

112. Kanda N, Tamaki K (1998) Ganglioside GQ1b enhances Ig production by human PBMCs. J Allergy Clin Immunol 102: 813-820.

113. Kanda N, Watanabe S (2000) Ganglioside GD1a enhances immunoglobulin production by human peripheral blood mononuclear cells. Exp Hematol 28: 672-679.

114. Kimata H, Yoshida A (1994) Differential effects of gangliosides on Ig production and proliferation by human B cells. Blood 84: 1193-1200.

115. Lee AF, Sieling PA, Lee DJ (2013) Immune correlates of melanoma survival in adoptive cell therapy. Oncoimmunology 2: e22889.

116. Nakamori M, Iwahashi M, Nakamura M, Ueda K, Zhang X, et al. (2003) Intensification of antitumor effect by $\mathrm{T}$ helper 1-dominant adoptive immunogene therapy for advanced orthotopic colon cancer. Clin Cancer Res 9: 2357-2365.

117. Sharma S, Stolina M, Lin Y, Gardner B, Miller PW, et al. (1999) T cellderived IL-10 promotes lung cancer growth by suppressing both $\mathrm{T}$ cell and APC function. J Immunol 163: 5020-5028.

118. Pellegrini P, Berghella AM, Del Beato T, Cicia S, Adorno D, et al. (1996) Disregulation in TH1 and TH2 subsets of CD4+ T cells in peripheral blood of colorectal cancer patients and involvement in cancer establishment and progression. Cancer Immunol Immunother 42: 1-8.

119. Baeuerle PA, Henkel T (1994) Function and activation of NF-kappa B in the immune system. Annu Rev Immunol 12: 141-179. 
120. Uzzo RG, Rayman P, Kolenko V, Clark PE, Cathcart MK, et al. (1999) Renal cell carcinoma-derived gangliosides suppress nuclear factorkappaB activation in T cells. J Clin Invest 104: 769-776.

121. Thornton MV, Kudo D, Rayman P, Horton C, Molto L, et al. (2004) Degradation of NF-kappa B in T cells by gangliosides expressed on renal cell carcinomas. J Immunol 172: 3480-3490.

122. Crespo FA, Sun X, Cripps JG, Fernandez-Botran R (2006) The immunoregulatory effects of gangliosides involve immune deviation favoring type-2 T cell responses. J Leukoc Biol 79: 586-595.

123. Rayman P, Wesa AK, Richmond AL, Das T, Biswas K, et al. (2004) Effect of renal cell carcinomas on the development of type $1 \mathrm{~T}$-cell responses. Clin Cancer Res 10: 6360S-6S.

124. Irani DN, Lin KI, Griffin DE (1996) Brain-derived gangliosides regulate the cytokine production and proliferation of activated T cells. J Immunol 157: 4333-4340.

125. Biswas S, Biswas K, Richmond A, Ko J, Ghosh S, et al. (2009) Elevated levels of select gangliosides in $\mathrm{T}$ cells from renal cell carcinoma patients is associated with T cell dysfunction. J Immunol 183: 5050-5058.

126. Kudo D, Rayman P, Horton C, Cathcart MK, Bukowski RM, et al. (2003) Gangliosides expressed by the renal cell carcinoma cell line SK-RC-45 are involved in tumor-induced apoptosis of $\mathrm{T}$ cells. Cancer Res 63: 1676-1683.

127. Sa G, Das T, Moon C, Hilston CM, Rayman PA, et al. (2009) GD3, an overexpressed tumor-derived ganglioside, mediates the apoptosis of activated but not resting T cells. Cancer Res 69: 3095-3104.

128. Kanda N, Watanabe S (2001) Gangliosides GD1b, GT1b, and GQ1b enhance IL-2 and IFN-gamma production and suppress IL-4 and IL-5 production in phytohemagglutinin-stimulated human T cells. J Immunol 166: $72-80$.

129. Li Y, Wong KK, Matsueda S, Efferson CL, Chang DZ, et al. (2006) Mitogen stimulation activates different signaling pathways in early- and late-divided $\mathrm{T}$ cells as revealed by cDNA microarray analysis. Int J Mol Med 18: 1127-1139.

130. Cantrell DA, Smith KA (1984) The interleukin-2 T-cell system: a new cell growth model. Science 224: 1312-1316.

131. Chu JW, Sharom FJ (1993) Gangliosides inhibit T-lymphocyte proliferation by preventing the interaction of interleukin- 2 with its cell surface receptors. Immunology 79: 10-17.

132. Chu JW, Sharom FJ (1995) Gangliosides interact with interleukin-4 and inhibit interleukin-4-stimulated helper T-cell proliferation. Immunology 84: 396-403.

133. Aerts JG, Hegmans JP (2013) Tumor-specific cytotoxic T cells are crucial for efficacy of immunomodulatory antibodies in patients with lung cancer. Cancer Res 73: 2381-2388.

134. McKallip R, Li R, Ladisch S (1999) Tumor gangliosides inhibit the tumor-specific immune response. J Immunol 163: 3718-3726.

135. Lee HC, Wondimu A, Liu Y, Ma JS, Radoja S, et al. (2012) Ganglioside inhibition of CD8+ $\mathrm{T}$ cell cytotoxicity: interference with lytic granule trafficking and exocytosis. J Immunol 189: 3521-3527.

136. Porcelli SA, Modlin RL (1999) The CD1 system: antigen-presenting molecules for $\mathrm{T}$ cell recognition of lipids and glycolipids. Annu Rev Immunol 17: 297-329.
137. Godfrey D, Hammond KJ, Poulton LD, Smyth MJ, Baxter AG (2000) NKT cells: facts, functions and fallacies. Immunol Today 21: 573-583.

138. Wu DY, Segal NH, Sidobre S, Kronenberg M, Chapman PB (2003) Cross-presentation of disialoganglioside GD3 to natural killer T cells. J Exp Med 198: 173-181.

139. Webb TJ, Li X, Giuntoli RL, Lopez PH, Heuser C, et al. (2012) Molecular identification of GD3 as a suppressor of the innate immune response in ovarian cancer. Cancer Res 72: 3744-3752.

140. Park JE, Wu DY, Prendes M, Lu SX, Ragupathi G, et al. (2008) Fine specificity of natural killer $\mathrm{T}$ cells against GD3 ganglioside and identification of GM3 as an inhibitory natural killer T-cell ligand. Immunology 123: 145-155.

141. Sriram V, Cho S, Li P, O'Donnell PW, Dunn C, et al. (2002) Inhibition of glycolipid shedding rescues recognition of a CD1+ T cell lymphoma by natural killer T (NKT) cells. Proc Natl Acad Sci U S A 99: 8197-8202.

142. Kushner BH, Cheung IY, Modak S, Kramer K, Ragupathi G, et al. (2014) Phase I trial of a bivalent gangliosides vaccine in combination with $\hat{\mathrm{I}}^{2}$ glucan for high-risk neuroblastoma in second or later remission. Clin Cancer Res 20: 1375-1382.

143. Lode HN, Schmidt M, Seidel D, Huebener N, Brackrock D, et al. (2013) Vaccination with anti-idiotype antibody ganglidiomab mediates a $\mathrm{GD}(2)$-specific anti-neuroblastoma immune response. Cancer Immunol Immunother 62: 999-1010.

144. Yvon E, Del Vecchio M, Savoldo B, Hoyos V, Dutour A, et al. (2009) Immunotherapy of metastatic melanoma using genetically engineered GD2-specific T cells. Clin Cancer Res 15: 5852-5860.

145. Ruf P, Schäfer B, Eissler N, Mocikat R, Hess J, et al. (2012) Ganglioside GD2-specific trifunctional surrogate antibody Surek demonstrates therapeutic activity in a mouse melanoma model. J Transl Med 10: 219.

146. Wondimu A, Zhang T, Kieber-Emmons T, Gimotty P, Sproesser K, et al. (2008) Peptides mimicking GD2 ganglioside elicit cellular, humoral and tumor-protective immune responses in mice. Cancer Immunol Immunother 57: 1079-1089.

147. Durrant LG, Noble P, Spendlove I (2012) Immunology in the clinic review series; focus on cancer: glycolipids as targets for tumour immunotherapy. Clin Exp Immunol 167: 206-215.

148. Heimburg-Molinaro J, Lum M, Vijay G, Jain M, Almogren A, et al. (2011) Cancer vaccines and carbohydrate epitopes. Vaccine 29: 8802-8826.

149. Andersson U, Butters TD, Dwek RA, Platt FM (2000) Nbutyldeoxygalactonojirimycin: a more selective inhibitor of glycosphingolipid biosynthesis than $\mathrm{N}$-butyldeoxynojirimycin, in vitro and in vivo. Biochem Pharmacol 59: 821-829.

150. Guerrera M, Ladisch S (2003) N-butyldeoxynojirimycin inhibits murine melanoma cell ganglioside metabolism and delays tumor onset. Cancer Lett 201: 31-40.

151. Ranes MK, El-Abbadi M, Manfredi MG, Mukherjee P, Platt FM, et al. (2001) N -butyldeoxynojirimycin reduces growth and ganglioside content of experimental mouse brain tumours. Br J Cancer 84: 1107-1114.

152. Liu Y, Wondimu A, Yan S, Bobb D, Ladisch S (2013) Tumor gangliosides accelerate murine tumor angiogenesis. Angiogenesis . 